\title{
STUDY ON THE EFFECTIVE APPLICATION OF BACTERIAL $\alpha$-AMYLASE FOR BATCH LIQUEFACTION
}

\author{
Stepan Melnyk ${ }^{1,}$, Yuriy Melnyk ${ }^{1}$, Bohdan Dzinyak ${ }^{1}$, Zorian Pikh ${ }^{1}$
}

https://doi.org/10.23939/chcht14.02.271

\begin{abstract}
The influence of the bacterial $\alpha$-amylase type and temperature on the accumulation of soluble dry matter and reducing sugars during fermentation of wheat batch has been investigated. The correlation between thermal stability of $\alpha$-amylase and process parameters is shown. The initial activity of the enzyme preparation affects the starch hydrolysis intensity. The change in the enzymes activity, occurred due to their inactivation at high temperatures, affects the maximum content of dry matter and reducing sugars in the liquefied matter.
\end{abstract}

Keywords: liquefaction, hydrolysis, $\alpha$-amylase, dry matter, reducing sugars.

\section{Introduction}

The application of enzyme preparations (EP) in food industry allows to improve existing technologies and to reduce their resource and energy intensities. At the same time, in order to maximize the effective use of enzymes in the technological process, it is advisable to know the optimal conditions for their action. Such data are suggested by manufacturers to use EP in a particular process. Therefore, in order to extend the application area of EP, which are used, for example, in brewing and adjacent fermentation industries, in particular alcohol production, it is necessary to evaluate the EP efficiency in comparison with known preparations tested in practice.

Another problem is the need to correct the technological regime during the processing of each type of raw material and the replacement of one EP with others. Since the significant dependence of enzymes thermal stability on temperature is known, it is important to establish the relationship between the EP activity, its change in time and the technological parameters of the process, obtained with the use of this preparation.

The processes of liquefaction and saccharification of cereals and potato starch are the basis for the production of alcohol, beer, starch syrup, glucose and maltose syrups, etc. Implementation of these industrial processes today is impossible without EP [1].

\footnotetext{
${ }^{1}$ Lviv Polytechnic National University,

12, Bandera St., 79013 Lviv, Ukraine

stepan.r.melnyk@lpnu.ua

(c) Melnyk S., Melnyk Yu., Dzinyak B., Pikh Z., 2020
}

The process of starch liquefaction requires the use of thermostable bacterial $\alpha$-amylase, which exhibits high activity at temperatures from 343 to $373 \mathrm{~K}$. Such thermostability is due to enzymes derived from microorganisms $B$. licheniformis or B. stearothermophilus [2].

Recently, the regularities of starch hydrolysis have been studied in detail for obtaining molasses and sugar syrups. Li et al. [3] determined the regularities of corn starch liquefaction with bacterial $\alpha$-amylase (Liquozyme SCDS) at $363 \mathrm{~K}$; dry matter content in starch was $20-60 \%$. It has been shown that high content of dry matter (40-60\%) requires high consumption of $\alpha$-amylase to produce a liquefied starch with a content of reducing sugars of $9-15 \%$.

The efficiency of bacterial $\alpha$-amylase used in brewing is determined by achieving high values of extract yield, extraction, total enzymatic extract, and low value of the resulted wort viscosity. Nic Phiarais et al. [4] showed the improvement of the above parameters during the production of buckwheat wort with the increase in Hitempase 2XL content. A high enzyme level is achieved by combining $30 \%$ of biocellulose and $70 \%$ of Hitempase 2XL.

The increase in the content of Hitempase 2XL in combination with Bioglucanase-TX and Brewers protease during a sorghum processing provides approximately $45 \%$ of free amine nitrogen, while the excess of the Brewers protease - not more than $15 \%$. The increase in Bioglucanase-TX content in the mixture in no way affects the accumulation of amine nitrogen [5].

It has been shown in [6] that MATS L Classic EP increases the content of extracts in a beer wort by $5.1 \%$, and the content of reducing sugars (recalculated as a maltose) - by $11.5 \%$. The yield of extracts from malt increases by $3.7 \%$.

Currently, the literature contains only recommendations for the use of Hitempase 2XL in the production of ethyl alcohol. Nasidi et al. [7] showed that the mixture of EP (Promalt, Bioglucanase ME1250L, Hitempase 2XL, Promalt 4TR and Termamyl 120L) allows to convert the spoiled grains of sorghum into bioethanol. The main attention was paid to the influence of the type of raw material on the technological parameters of the process. Ubwa et al. [8] studied alcohol production from corn and manioc using various combinations and concentrations of 
EP containing $\alpha$-amylase (Hitempase and Fungamyl), glucoamylase (AMG) and proteolytic enzymes (Bioprotease). The authors point out that the change in the concentration of EP, especially Hitempase and AMG, affects the yield of bioethanol and its purity. These values were found to be lower during the processing of manioc compared with those using corn as a raw material.

The abovementioned data correlate with the investigation results regarding the corn-based spirits using Hitempase 2XL, Olcoclast DGS and Biocellulase W [9]. Although Hitempase 2XL, in terms of its amylolytic activity and thermal stability, is inferior to Termamyl CS, which is widely used in the production of rectified alcohol, the optimal conditions for the alcohol standard yield were established by adjusting the technological regime of the corn batch liquefaction process. The authors recommend the temperature of $348-353 \mathrm{~K}$ for the first $1.5-2 \mathrm{~h}$ of the process and then it is necessary to increase it to $363 \mathrm{~K}$. The total process time should be $3 \mathrm{~h}$. A relatively low temperature of liquefaction will prevent inactivation of $\alpha$ amylase, and its further increase to $363 \mathrm{~K}$ will contribute to batch pasteurization.

Simultaneous usage of amylolytic Hitempase 2XL and Olcoclast DGS with proteolytic Profix and Promalt also provides a high yield of rye spirit [10]. For different mixtures of EP, the optimum process temperature should not exceed $353 \mathrm{~K}$.

Step-by-step addition of Hitempase 2XL during the liquefaction of sorghum, african millet or sweet potato batch within the range of 333-368 K (beginning and end of starch gelling) improves the completeness of the fermentation process with a corresponding increase in the yield of bioethanol [11].

Thus, it should be noted that the temperature is a significant factor affecting the efficiency of enzymes in the technological process of batch liquefaction. So, determination of the relationship between the thermal stability of enzymes which are part of EP, and the process parameters will allow to determine the optimal conditions of the process and improve its technical and economic characteristics.

To determine the mechanism of one-type chemical, physical, physico-chemical and biological transformations, the data regarding kinetic and thermodynamic compensating effects which are present or absent in the investigated processes, are often used [12].

In particular, Garvin et al. [12] established isokinetic peculiarities for the destruction of various microorganisms. Gladii et al. [13] determined the activation and kinetic parameters of the temperature dependences of non-catalytic and catalytic acylation processes of 2-hydroxyethyl methacrylate and hydroxyhexaoxypropyl acrylate by phthalic anhydride. The kinetic compensating effect is clearly observed in this work. The compensation effect of mixing is also observed in [14] to dissolve 2-methyl-5arylfuran-3-carboxylic acids in all solvents containing the carbonyl group, etc.
Since isokinetic dependencies are closely related to temperature, their determination for the enzymes inactivation is of great interest. This is important from the standpoint of establishing the temperature effect on the mechanism of enzymes destruction, as well as for the explanation how enthalpy or entropy controls the destruction resistance of enzymes.

Therefore, the aim of our research was to compare the efficiency of the thermostable bacterial $\alpha$-amylase MATS L Classic and Hitempase 2XL with Termamyl 120L in the process of starch-based batch liquefaction and to establish the relationship between thermal stability of enzymes and technological parameters of the process.

\section{Experimental}

Wheat with starch and moisture content of 52.4 and $9.6 \%$, respectively, was used as a raw material. All impurities were separated by sifting through a set of sieves before milling the wheat.

For wheat batch liquefaction the enzyme preparations of thermostable bacterial $\alpha$-amylase were used:

- MATS L Classic (DSM), which is used in brewing for the hydrolysis of starch. The operating temperature of EP is $343-373 \mathrm{~K}$, the optimum temperature is 366-368 K; MATS L Classic is inactivated during boiling;

- Hitempase 2XL (Kerry Foods Ingredients), which enhances the biological and colloidal stability of beer, increases the extract yield and the degree of beer fermentation. EP Hitempase 2XL is stable during the wort boiling (up to $378 \mathrm{~K}$ );

- Termamyl 120L (Novozymes), which is used both in brewing and in the alcohol production for the starch liquefaction. The optimum temperature is $353-368 \mathrm{~K}$.

To prepare the batch, wheat was milled to provide $100 \%$ passage of grains through a sieve with holes diameter of $1 \mathrm{~mm}$. A round-bottomed three-necked flask equipped with a mechanical stirrer and a backflow condenser was loaded with $180 \mathrm{~cm}^{3}$ of tap water. $60 \mathrm{~g}$ of milled wheat were added under stirring. Then the mixture was heated in a water bath to the liquefaction temperature and $0.06 \mathrm{~cm}^{3}$ of EP was added by a pipette. The samples were withdrawn after definite periods of time and filtrated using 6-8 layers of gauze.

In all experiments the wheat:water ratio was $1: 3$ (w/w), and EP dose was $1 \mathrm{dm}^{3} / \mathrm{t}$ of wheat.

To determine the content of dry matter the IRF-1 refractometer was used; the content of reducing sugars was determined by the permanganate method [15]. All measurements were carried out three times at $293 \mathrm{~K}$. The measurement errors were $2.5 \%$ (for dry matter content) and $4 \%$ (for reducing sugars).

Thermal stability of EP aqueous solutions $\left(1 \mathrm{~cm}^{3}\right.$ EP per $100 \mathrm{~cm}^{3}$ of solution) was checked by a thermostatic testing at a liquefaction temperature. The amylolytic (dextrinolytic) activity of the enzymes was determined after 
40 min of holding at 353,363 and $371 \mathrm{~K}$, according to the method described in [15]. The relative error was calculated using three measurements at each control point.

\section{Results and Discussion}

The regularities of liquefaction with the use of MATS L Classic, Hitempase 2XL and Termamyl 120L were investigated within a recommended temperature range of 353-371 K. The dynamics of changes in the dry matter content over time at the same temperature for each of three studied EP is represented in Fig. 1.

At the temperature of $353 \mathrm{~K}$, at the initial stage of liquefaction (for the first $30 \mathrm{~min}$ ), the higher activity is observed for MATS L Classic (Fig. 1a). In its presence the dry matter content is above $8 \%$ compared with $\sim 7 \%$ in the presence of Termamyl 120L and Hitempase 2XL. But it should be noted that in this case the intensity of dry matter accumulation sharply decreases with the increase in starch hydrolysis degree, and the formation of dry matter becomes slower after 100-120 min. The dynamics of dry matter accumulation in the presence of Termamyl $120 \mathrm{~L}$ and Hitempase 2XL is practically the same, but in the presence of Termamyl EP its content is always higher by $\sim 0.5 \%$.

The increase in temperature by $10 \mathrm{~K}$ does not change the general principles (Fig. 1b), but at the $30^{\text {th }}$ minute of the process the maximum dry matter content of $10.1 \%$ is observed in the liquidied matter obtained with the use of Hitempase 2XL (cf. $9.3 \%$ in the presence of MATS L Classic and $7.9 \%$ in the presence of Termamyl 120L). It should be noted that further intensity of starch hydrolysis in the presence of Termamyl $120 \mathrm{~L}$ increases. Thus, after $60 \mathrm{~min}$ the dry matter content in the presence of mentioned EP exceeds the value obtained in the presence of Hitempase 2XL by $0.3-0.5 \%$. Under same conditions the starch hydrolysis in the presence of MATS L Classic becomes slower, and the dry matter content for the next 120 minutes increases only by $\sim 1 \%$.

At the temperature of $371 \mathrm{~K}$, after $30 \mathrm{~min}$ of liquefaction, the highest activity is observed for Hitempase 2XL, in the presence of which the dry matter content is $9.8 \%$ (Fig. 1c). In the presence of MATS L Classic it is
$8.6 \%$, in the presence of Termamyl $120 \mathrm{~L}-$ only $6.4 \%$. At the $60^{\text {th }}$ minute the highest value $(12.4 \%)$ of dry matter content remains for Hitempase 2XL, but in the presence of Termamyl $120 \mathrm{~L}$ it increases to $11.9 \%$. At the $180^{\text {th }}$ minute, on the contrary, the content of dry matter in the presence of Termamyl $120 \mathrm{~L}$ reaches $15.8 \%$, and in the presence of Hitempase $2 \mathrm{XL}$ - only $14.5 \%$. After 60 min the hydrolysis of wheat starch by the amylolytic enzymes of MATS L Classic becomes slower (the same as at $363 \mathrm{~K}$ ), and the dry matter content increases by only $1.3 \%$.

Obviously, in the process of starch hydrolysis, the increase in the content of reducing sugars with time is observed (Fig. 2), the same as the content of soluble dry matter. However, it should be noted that the difference between the curves of the accumulation of reducing sugars for various EP at different temperatures is more significant, compared to the curves of soluble dry matter.

As can be seen from Fig. 2a, at $353 \mathrm{~K}$ the highest saccharifying ability was found for MATS L Classic: in the time interval of $60-120 \mathrm{~min}$ the content of reducing sugars increases from 1.0 to $1.78 \%$. In the presence of Termamyl $120 \mathrm{~L}$ and Hitempase 2XL, the intensity of reducing sugars accumulation is practically the same, and their content varies from $0.43-0.47$ to $0.84-0.97 \%$, respectively. With the temperature increase by $10 \mathrm{~K}$, the saccharifying ability of MATS L Classic remains sufficiently high (Fig. 2b). The maximum content of reducing sugars in the batch for $180 \mathrm{~min}$ is $1.44 \%$ (cf. with $1.27 \%$ for Termamyl $120 \mathrm{~L}$, and $0.48 \%$ for Hitempase $2 \mathrm{XL}$ ).

At the temperature of $371 \mathrm{~K}$, the highest content of reducing sugars $(0.93 \%)$ is achieved for $180 \mathrm{~min}$ in the presence of Termamyl 120L (Fig. 2c). When using MATS L Classic and Hitempase 2XL the values are 0.88 and $0.53 \%$, respectively.

Thus, the highest saccharifying ability was found to be for MATS L Classic.

The amylolytic activity of EP in $1 \%$ aqueous solutions at the liquefaction temperature was studied to determine the thermal stability of the above mentioned bacterial $\alpha$-amylase. The results of the experiments are represented in Table 1.

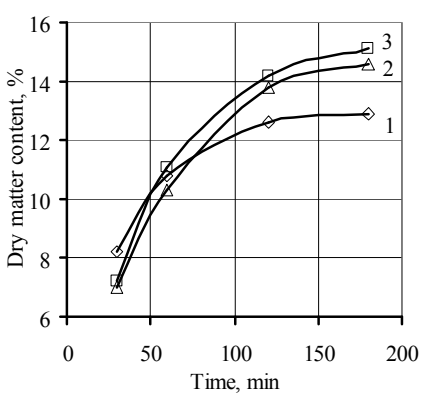

a)

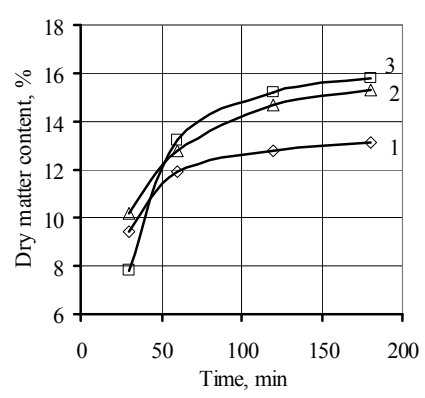

b)

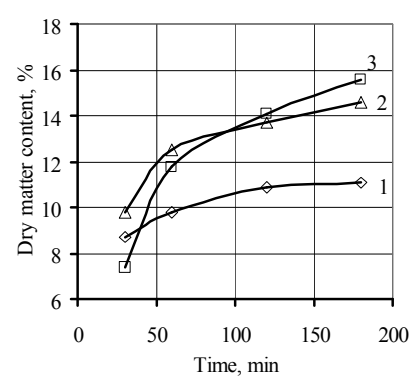

c)

Fig. 1. Dry matter content $v s$. time at $353 \mathrm{~K}$ (a), $363 \mathrm{~K}$ (b) and $371 \mathrm{~K}$ (c) in the presence of MATS L Classic (1); Hitempase 2XL (2) and Termamyl 120L (3) 


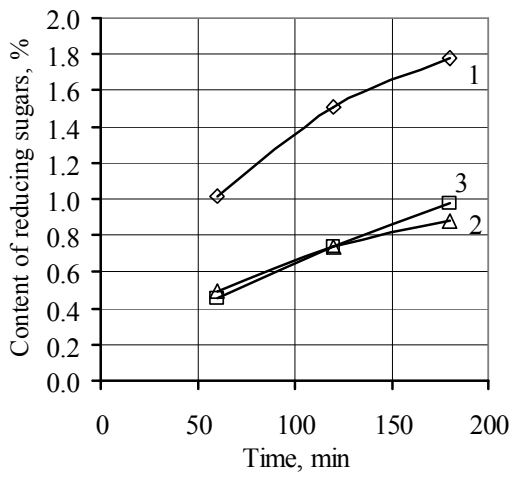

a)

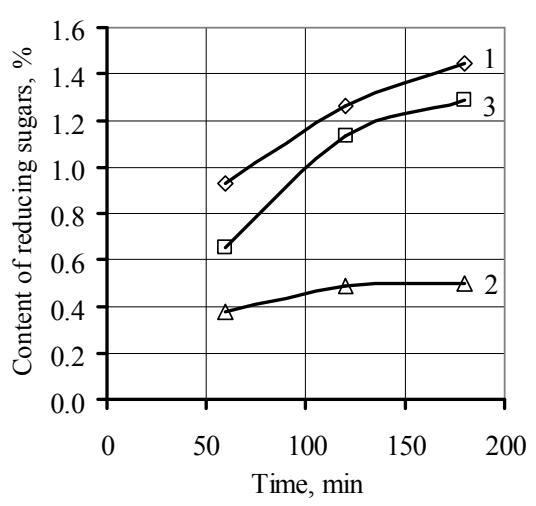

b)

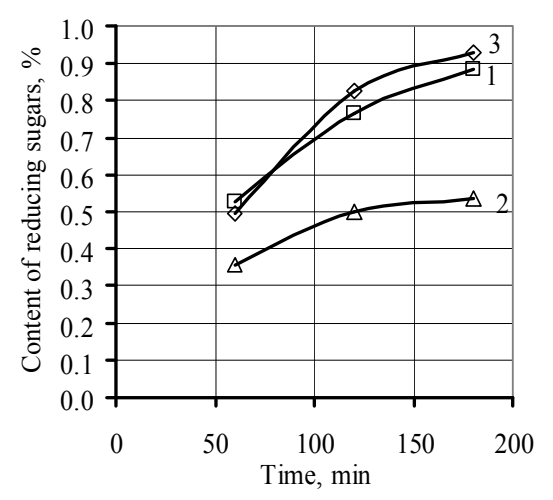

c)

Fig. 2. Content of reducing sugars vs. time at $353 \mathrm{~K}$ (a), $363 \mathrm{~K}$ (b) and $371 \mathrm{~K}$ (c) in the presence of MATS L Classic (1); Hitempase 2XL (2) and Termamyl 120L (3)

Table 1

Change in amylolytic activity of $1 \%$ aqueous solutions of enzymes during thermostatting

\begin{tabular}{|c|c|c|c|}
\hline \multirow{2}{*}{ Time, $\min$} & \multicolumn{3}{|c|}{ Amylolytic activity, $\mathrm{U} / \mathrm{cm}^{3}$} \\
\hline & $353 \mathrm{~K}$ & $363 \mathrm{~K}$ & $371 \mathrm{~K}$ \\
\hline \multicolumn{4}{|c|}{ MATS L Classic } \\
\hline 0 & $905 \pm 20$ & $845 \pm 15$ & $715 \pm 15$ \\
\hline 40 & $20 \pm 4$ & $10 \pm 1$ & 0 \\
\hline \multicolumn{4}{|c|}{ Hitempase 2XL } \\
\hline 0 & $695 \pm 15$ & $975 \pm 20$ & $950 \pm 20$ \\
\hline 40 & $455 \pm 10$ & $35 \pm 2$ & $10 \pm 1$ \\
\hline \multicolumn{4}{|c|}{ Termamyl 120L } \\
\hline 0 & $680 \pm 15$ & $540 \pm 10$ & $410 \pm 10$ \\
\hline 40 & $640 \pm 15$ & $350 \pm 10$ & $185 \pm 5$ \\
\hline
\end{tabular}

It is obvious that both temperature and time significantly affect the amylolytic activity of EP $1 \%$ aqueous solutions. Thus, with the increase in temperature from 353 to $371 \mathrm{~K}$, the activity of the bacterial $\alpha$-amylase of MATS L Classic and Thermamyl 120L decreases from 905 to 715 and from 680 to $410 \mathrm{U} / \mathrm{cm}^{3}$, respectively. The amylolytic activity of Hitempase 2XL increases from $695 \mathrm{U} / \mathrm{cm}^{3}$ at $353 \mathrm{~K}$ to $975 \mathrm{U} / \mathrm{cm}^{3}$ at $363 \mathrm{~K}$ and then slightly decreases to $950 \mathrm{U} / \mathrm{cm}^{3}$ at $371 \mathrm{~K}$.

The obtained values of amylolytic activity after holding the aqueous solution of each EP at the temperature of $353-371 \mathrm{~K}$ for $40 \mathrm{~min}$ shows the inactivation of $\alpha$-amylase MATS L Classic to be the most rapid. Moreover, this EP is completely destroyed at $371 \mathrm{~K}$. For $40 \mathrm{~min}$ the amylolytic activity of Hitempase 2XL during its holding at $353 \mathrm{~K}$ decreases from 695 to $455 \mathrm{U} / \mathrm{cm}^{3}$. As the thermostatting temperature increases, the decrease in Hitempase 2XL activity is more significant: to $35 \mathrm{U} / \mathrm{cm}^{3}$ at $363 \mathrm{~K}$ and to $10 \mathrm{U} / \mathrm{cm}^{3}$ at $371 \mathrm{~K}$. The activity of Thermamyl $120 \mathrm{~L}$ during thermostatting at $353 \mathrm{~K}$ decreases from 680 to $640 \mathrm{U} / \mathrm{cm}^{3}$, at $363 \mathrm{~K}$ - from 540 to $350 \mathrm{U} / \mathrm{cm}^{3}$, and at $371 \mathrm{~K}-$ from 410 to $185 \mathrm{U} / \mathrm{cm}^{3}$.

So, the intensity of the accumulation of soluble dry matter and reducing sugars in the liquefied matter depends on the process temperature and the type of enzyme preparation.
The common feature of the investigated EP is that the maximum amount of dry matter in their presence accumulates for the first 30-60 min of the process (Fig. 1). Further deceleration of starch hydrolysis can be explained not only by the decrease in the reaction rate due to the substrate concentration decrease, but also by a partial inactivation of $\alpha$ amylase under the influence of temperature. The assumption made above is also confirmed by the decrease in the intensity of reducing sugars accumulation (Fig. 2). At $353 \mathrm{~K}$ the inactivation of enzymes is less evident, therefore the curves of dry matter accumulation do not have typical "plateau", observed at higher temperatures (Fig. 1b).

The initial amylolytic activity of EP affects the initial stage, in particular the intensity of starch hydrolysis. The change in the enzymes activity with time and the degree of their inactivation at high temperatures influence the accumulation of the maximum possible content of dry matter and reducing sugars in the liquefied matter, respectively (Table 1, Fig. 1-2).

Previously [6] we calculated the activation energy of the inactivation reaction of MATS L Classic $\left(E_{A}=134 \pm 14 \mathrm{~kJ} / \mathrm{mol}\right)$, and the preexponential factor $\left(k_{0}=8.7 \cdot 10^{16} \mathrm{~s}^{-1}\right)$. The activation energy of Hitempase 2XL $\mathrm{EP}$ is $125 \mathrm{~kJ} / \mathrm{mol}$, and the preexponential factor is $1.3 \cdot 10^{15} \mathrm{~s}^{-1}$ [16]. 
According to the results of [17] and taking into account that the inactivation of enzymes can be described by the kinetic equation of the first order, we have calculated the activation energy of the inactivation reaction of Termamyl $120 \mathrm{~L}\left(E_{a}=243 \mathrm{~kJ} / \mathrm{mol}\right)$, and the preexponential factor $\left(k_{0}=2.5 \cdot 10^{31} \mathrm{~s}^{-1}\right)$.

The calculated rate constants of the inactivation reaction of enzymes of the investigated EP depending on the temperature are shown in Table 2. The slightest influence of temperature is observed for Termamyl $120 \mathrm{~L}$, which is practically non-inactivated at $353 \mathrm{~K}$. At the same temperature, the thermal stability of Hitempase 2XL and MATS L Classic is less by 15 and 46.9 times, respectively. With the increase in temperature the general regularity remains, but the difference between the rate constants becomes smaller. At $363 \mathrm{~K}$ thermostability of Termamyl $120 \mathrm{~L}$ and MATS L Classic differs by 16.9 times, and at $371 \mathrm{~K}$ - only by 7.7 times (Table 2).

It is evident that the environment can protect the enzymes from the influence of temperature, so inactivation of EP under liquefaction conditions will be lower. At the same time, it should be noted that the intensity of dry matter and reducing sugars accumulation is well consistent with the values of thermal stability for all investigated EP. Therefore, these studies may be used to predict the efficacy of other EP in the production of alcohol.

Using data from $[6,16,17]$, the thermodynamic activation parameters, in particular the enthalpy $\Delta H^{\#}$, the entropy $\Delta S^{\#}$, and the Gibbs energy $\Delta G^{\#}$, were calculated for investigated EP. The results of these calculations for the average temperature of $363 \mathrm{~K}$ are represented in Table 3.

To determine the isokinetic temperature of $\alpha$-amylase inactivation reaction for investigated $\mathrm{EP}$, the logarithmic dependence of the preexponential factor $\ln k_{0}$ on the activation energy was constructed. As can be seen from Fig. $3 \mathrm{a}$, this dependence is linear. The isokinetic temperature of the inactivation reaction is calculated from the straight line slope according to Eq. (1):

$$
T_{i s o}=\frac{1}{b \cdot R}
$$

where $R$ is an absolute gas constant $(R=8.314 \mathrm{~J} / \mathrm{mol} \cdot \mathrm{K})$.
The calculated temperature of $384 \mathrm{~K}$ is also equal to the slope determined according to the dependence $\Delta H^{\#}=f\left(\Delta S^{\#}\right)$ characterizing a thermodynamic compensation effect of $\alpha$-amilase inactivation reaction (Fig. 3b).

The value of $\Delta G^{\sharp} / R T$ does not depend on the activation enthalpy $\Delta H^{\#}$ calculated for each temperature $T$ (Fig. 4). The absence of such dependence confirms the exposed compensation effects [18]. Deviations of $\Delta G^{\#} / R T$ values from their mean values do not exceed $\pm 6 \%$.

The determined isokinetic temperature of the enzymes inactivation reaction is higher than the operating temperatures (353-371 K) of EP usage in batch liquefaction. It can be concluded that the change in the rate constant of $\alpha$ amylase inactivation depends more on the change in the activation energy than on the preexponent change. So, the reaction is controlled by an enthalpy. Obviously, for the liquefaction temperature, which is lower than the isokinetic temperature, the sensitivity of the $\alpha$-amylase inactivation rate to the change in the activation energy of this reaction will be high. This results in a sharp increase in the rate constant of the inactivation reaction even with a slight increase in temperature.

In general, the determination of kinetic parameters of bacterial $\alpha$-amylase inactivation process for any EP will allow to predict its thermal stability during starch hydrolysis. Obviously, the control of batch liquefaction temperature is a key factor in maintaining sufficient enzymatic activity of bacterial $\alpha$-amylase during the whole process.

The experimental results show Hitempase 2XL to be more effective compared with MATS L Classic for batch liquefaction during alcohol production from wheat. At the same time, along with dextrinolytic activity, MATS L Classic exhibits a sufficiently high saccharifying ability. So, we propose it to be used at the saccharification stage of liquefied batch combined with EP of fungus glucoamylase. The thermal fermentation of wheat batch in the presence of Hitempase 2XL at optimum temperature of $363 \mathrm{~K}$, which is lower than the maximum temperature recommended by the manufacturer, is in agreement with the similar regularities defined for Termamyl 120L [19].

Table 2

Calculated rate constants of bacterial $\alpha$-amylase inactivation in EP and constants ratio

\begin{tabular}{|c|c|c|c|c|c|c|}
\hline \multirow{3}{*}{ EP } & \multicolumn{3}{|c|}{ Rate constants, $\mathrm{s}^{-1}$} & \multicolumn{3}{|c|}{ Constants ratio } \\
\hline & \multicolumn{6}{|c|}{ Temperature, $\mathrm{K}$} \\
\hline & 353 & 363 & 371 & 353 & 363 & 371 \\
\hline MATS L Classic & 0.00129 & 0.0045 & 0.0118 & 46.9 & 16.9 & 7.7 \\
\hline Hitempase 2XL & 0.00041 & 0.0013 & 0.0033 & 15.0 & 5.0 & 2.1 \\
\hline Termamyl 120L & 0.00003 & 0.0003 & 0.0015 & 1.0 & 1.0 & 1.0 \\
\hline
\end{tabular}

Table 3

Thermodynamic characteristics of $\alpha$-amilase inactivation reaction calculated for $373 \mathrm{~K}$

\begin{tabular}{|l|c|c|c|}
\hline Index & MATS L Classic & Hitempase 2XL & Termamyl 120L \\
\hline$\Delta H^{+}, \mathrm{J} \cdot \mathrm{mol}^{-1}$ & 130900 & 121900 & 239900 \\
\hline$\Delta S^{\#}, \mathrm{~J} \cdot \mathrm{mol}^{-1} \cdot \mathrm{K}^{-1}$ & 69.3 & 34.3 & 346 \\
\hline$\Delta G^{+}, \mathrm{J} \cdot \mathrm{mol}^{-1}$ & 105060 & 109100 & 110800 \\
\hline
\end{tabular}




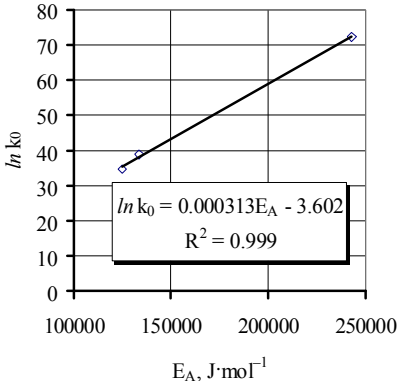

a)

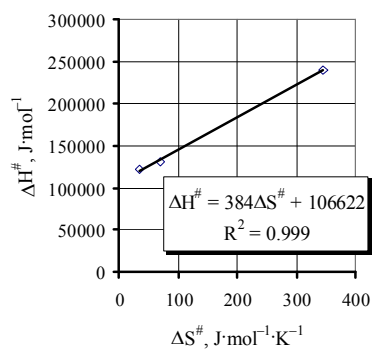

b)

Fig. 3. Isokinetic (a) and thermodynamic (b) dependencies for $\alpha$-amilase inactivation reaction

\section{Conclusions}

The dynamics of soluble dry matter and reducing sugars accumulation in the liquefied batch is influenced both by the type of enzyme preparation and the fermentation temperature. The highest activity in the liquefaction process in relation to the accumulation of dry matter was found to be for Termamyl 120L, and in relation to reducing sugars - for MATS L Classic.

The intensity of the liquefaction process and the content of dry matter and reducing sugars are in a good agreement with the thermal stability of $1 \%$ aqueous solutions of investigated enzyme preparations of bacterial $\alpha$-amylase (MATS L Classic, Hitempase 2XL and Termamyl 120L) that can be used to predict the enzymes action in hydrolytic processes. The initial amylolytic activity of EP affects the intensity of starch hydrolysis at the initial stage of liquefaction, and the change in the enzymes activity with time, as well as the degree of their inactivation at high temperatures - on the maximum possible content of dry matter and reducing sugars.

The compensation isokinetic and thermodynamic effects of $\alpha$-amylase inactivation reaction in the investigated enzyme preparations have been determined. Isokinetic temperature of enzymes inactivation was found to be $384 \mathrm{~K}$. This indicates that the reaction is controlled by the enthalpy component, in particular, the activation energy.

The limiting fermentation temperature when using Hitempase 2XL should not exceed $363 \mathrm{~K}$. Taking into account the thermal stability of MATS L Classic, it is proposed to use it at the saccharification stage of the liquefied batch combined with EP of fungus glucoamylase.

\section{References}

[1] Vengadaramana A.: Sch. Acad. J. Pharm., 2013, 2, 209.

[2] Prakash O., Jaiswal N.: Appl. Biochem. Biotech., 2010, 160, 2401. https:/doi.org/10.1007/s12010-009-8735-4

[3] Li Z., Wang D., Shi, Y.-C.: Starch, 2019, 71, 1800142.

https:/doi.org/10.1002/star.201800142

[4] Nic Phiarais B., Schehl B., Oliveira J. et al.: J. Inst. Brew., 2006, 112, 324. https://doi.org/10.1002/j.2050-0416.2006.tb00738.x

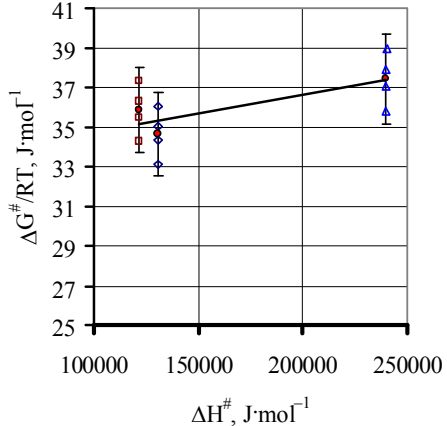

Fig. 4. The $\Delta G^{\#} / R T$ value $v s$. activation enthalpy

[5] Desobgo Z., Nso E., Tenin D.: J. Brew. Dist., 2011, 2, 28.

[6] Melnyk S., Melnyk Yu.., Rohovyi Yu. et al.: Visnyk Nats. Univ. "Lvivska Polytekhnika", 2005, 529, 103.

[7] Nasidi M., Agu R., Deeni Y. et al:: Bioethanol, 2015, 1, 1. https:/doi.org/10.1515/bioeth-2015-0001

[8] Ubwa S., Nwadinigwe C. Ugalahi-Igbum G. et al.: Int. J. Modern Chem., 2012, 1, 1

[9] Levandovskyi L., Mudrak T., Shyian P. et al.: Naukovi Pratsi NUKhT, 2008, 24, 24.

[10] Levandovskyi L., Shyian P., Mudrak T. et al.: Kharchova i Pererobna Prom., 2007, 11, 15.

[11] Ubwa S., Abah J., Igbum O. et al.: Int. J. Renew. Energ. Res., 2013, 3, 24 .

[12] Garvin A., Ibarz R., Ibarz A.: Food. Res. Int., 2017, 96, 132. https:/doi.org/10.1016/j.foodres.2017.03.004

[13] Gladii A., Tsyupko F., Polyugyn I. et al.: Chem. Chem. Technol., 2015, 9, 267. https://doi.org/10.23939/chcht09.03.267

[14] Sobechko I., Dibrivnyil V., Horak Yu. et al.: Chem. Chem. Technol., 2017, 11, 397. https:/doi.org/10.23939/chcht11.04.397

[15] Polygalina C.: Tekhnokhimicheskii Kontrol Spirtovogo i LikeroVodochnogo Proizvodstv. Kolos, Moskva 1999.

[16] Melnyk Yu., Melnyk S., Mahorivska H.: Visnyk Nats. Univ.

"Lvivska Polytekhnika", 2012, 726, 95.

[17] Blishch R., Melnyk S.: Visnyk Nats. Univ. "Lvivska Polytekhnika", 2004, 516, 55 .

[18] Cornish-Bowden A.: J. Biosci. 2017, 42, 665. https://doi.org/10.1007/s12038-017-9719-0

[19] Marynchenko V., Melnyk S., Rosolova R.: Kharchova i Pererobna Prom., 2003, 1, 18.

Received: January 28, 2019/Revised: March 04, 2019 / Accepted: May 22, 2019

\section{ДОСЛДДЖЕННЯ ЕФЕКТИВНОСТІ ЗАСТОСУВАННЯ ПРЕПАРАТІВ БАКТЕРІАЛЬНОЇ व-АМІЛАЗИ ДЛЯ РОЗРІДЖЕННЯ ЗАМІСУ}

Анотація. Досліджено вилив виду ферментного препарату бактеріальної $\alpha$-амілази і температури на накопичення розчинних сухих речовин та редукуючих иукрів у прочесі термоферментативної обробки замісу з пшенииі. Показано кореляиію між термічною стабільністю $\alpha$-амілази і показниками процесу. Встановлено, що початкова активність ферментного препарату впливає на інтенсивність гідролізу крохмалю, а зміна активності ферментів внаслідок їх інактивацї̈ за високої температури - на максимальний вміст сухих речовин і редукуючих иукрів у розрідженій масі.

Ключові слова: розрідження, гідроліз, $\alpha$-амілаза, сухі речовини, редукуючі иукри. 